\title{
EXAMINATION OF MUSLIM CONSUMERS' INTENTIONS TO EAT AT FINE DINING RESTAURANTS
}

\author{
Muhammad Amiruddin Al- Farisi ${ }^{1}$, Latifah Putranti ${ }^{2}$ and \\ Nuraini Desty Nurmasari ${ }^{3}$ \\ ${ }^{1}$ Universitas Gadjah Mada, Indonesia, M.a.alfarisi04@gmail.com \\ ${ }^{2}$ Universitas PGRI Yogyakarta, Indonesia, Latifah@upy.ac.id \\ ${ }^{3}$ Universitas Gadjah Mada, Indonesia, nuraini.desty.n@mail.ugm.ac.id
}

\begin{abstract}
This paper aims to identify the functional, symbolic, hedonic and Islamic value constructs of Muslim consumers' satisfaction with fine dining restaurants. In addition, it develops the role of religiosity in the relationship between hedonic and Islamic symbolic values in consumer satisfaction and examines the effect of such satisfaction on the willingness to pay more. The method used in the research is based on a Structural Equation Modeling (SEM), with data collected using a questionnaire; 281 valid respondents took part in the study. The results show that in terms of the influence of the dimensions of perceived value in explaining customer satisfaction, the functional, hedonic and Islamic have has a positive and significant effect, whereas the symbolic value variable is is perceived to have no significant effect on satisfaction. Furthermore, customer satisfaction has a significant positive effect on the willingness to pay more. In comparison, religiosity does not moderate the effect of perceived symbolic value on consumer satisfaction. However, it does moderate the effect of hedonic and Islamic value.
\end{abstract}

Keywords: Perceived value, Muslim consumers, Consumer satisfaction, Post purchase. JEL classification: M31.

Article history:

Received : October 6, 2020

Revised : December 28, 2020

Accepted : February 3, 2021

Available online : February 28, 2021

https://doi.org/10.21098/jimf.v7i1.1334 


\section{INTRODUCTION}

\subsection{Background}

The importance of statements regarding Muslim consumption behaviour in the development of Muslim consumers as a potential global market. Lipka and Hacket (2015) state that the projected growth of Muslims will increase by 70\%, from 1.8 billion in 2015 to nearly 3 billion by 2060 . Indonesia is the country with the most Muslim adherents in the world, with a proportion of $88.1 \%$ of the total population, constituting 250 million people (Indonesia , 2015). The large number of Muslims in Indonesia means the related consumer segment has great potential to become a target market. Amongst the various industrial sectors in Indonesia, the food and beverage industry is a relatively developed one. Muslim consumers in Indonesia have the highest expenditure in the world, amounting to $\$ 169.7$ billion in 2016, above Turkey and Egypt (Thomson and Reuters, 2017).

In the culinary industry sub-sector, many concepts offer diversity and uniqueness, including fine dining restaurants. The data in this research come from the Indonesian Hotel and Restaurant Association (PHRI), which show that in the last three years such restaurants have shown a growth of $50 \%$. A MasterCard survey with a broader scope of research predicted this increase in the Asia Pacific context, with the forecast that millennials with an average age of 18-39 would go to fine dining restaurants at least once a month (Marketers Editor, 2016). Har (2008) defines a restaurant with a fine dining concept as one that provides the best service, an upmarket food and beverage menu, and a unique atmosphere and decoration. This type of restaurant also has professional and trained waiters, and it is not uncommon for diners to have to follow a specified dress code. According to Jin et al . (2015), besides food, fine dining restaurants provide customers with enjoyable social activities and dining experiences.

The development of marketing research topics from 1995-2014 has shifted from the orientation of marketing tactics to the delivery of values by marketers (Cho, Fu, \& Wu, 2017). According to Lee and Jeong (2014), value consists of two points of view, namely customer value and company value, which are interrelated and unified. Company value is that which is perceived by customers related to the company. On the other hand, customer value represents the motivation that forms a consumer's psychological self. When customers perceive that the company has a value following themselves, they tend to have a better and more profitable attitude towards the brand (Lee and Jeong, 2014). This is increasingly beneficial for marketers because it is considered that values are not easy to change because of cultural or other environmental influences (Atchison, 1990). It is also important because service providers or culinary industry activists must be able to understand the basic issues that Muslim consumers pay attention to, such as perceived value, in order to maintain the sustainability and development of the business (Eid, 2013; Adly \& Eid, 2017). The role of consumption is closely attached to one's faith, as faith is a measure of human behaviour (Mokhlis, 2009). In the context of consumer behaviour, the construct of religion relates to religiosity. Gayatri and Margee (2005) state that differences in the level of religiosity will affect consumer evaluation criteria when choosing products or services. In line with this opinion, Alam and Hisham (2011) state that religiosity has a significant influence on consumer behaviour in Malaysia. Finally, consumer religiosity is a 
different construct from perceived Islamic value. It is a value to which individuals adhere and are attached, and is related to high or low levels of commitment to the particular religion.

Few studies have discussed how perceived value can influence post-purchase behaviour in the context of the restaurant or hospitality industry based on a group of consumers who have the same religious background. One example is Yang and Mattila's (2016) research on the influence of post-purchase behaviour in the hospitality industry. According to them, further research should identify the perceived values of such behaviour because consumers may have different evaluation criteria depending on their respective characteristics. This is the basis for specialist research on Muslim respondents as they tend to have different characteristics. Research on consumer behaviour with regard to religious affiliation in the context of premium products or services continues to focus on the influence of consumer religiosity. For instance, research by Veer and Shankar (2011) found that products and services which were seen or considered to be luxurious were closely related to materialism. These findings support those of Iter (2017), who states that the relationship between materialism and religious values is contradictory. On the other hand, Bouslama (2017) states that a consumer's religiosity does not affect the consumption pattern of products or services in the luxury category. Denni and Tjiptono (2016) also support this finding, that when using luxury products, the value of extrinsic religiosity is positively related to purchase intention. Therefore, this study attempts to provide a more comprehensive explanation by involving aspects of perceived value and religiosity as moderating variables. There is a negative relationship between materialistic consumption behaviour and the religious values held by each individual. Few previous studies have identified perceived value. The application of measurement items for Muslim consumers related to the concept of fine dining will make a significant contribution to the generalisability of the findings. This research has also modified and added measurement items used in different contexts.

\subsection{Objective}

This study aims to: (1) examine the effect of functional value, symbolic value, hedonic value, and perceived Islamic value on consumer satisfaction; (2) examine the role of religiosity as a moderating variable in the relationship between these four values with regard to customer satisfaction; and (3) examine the effect of consumer satisfaction on the willingness to pay more.

The paper is organised as follows. Section 2 presents the literature review, while section 3 elaborates on the data and methodology. Section 4 comprises the results and discussion, and the final section concludes the study and provides its limitations and suggestions for future research.

\section{LITERATURE REVIEW}

\subsection{Background Theory}

The self-congruity theory developed by Sirgy (1985) proposes that self-conformity related to self-image and products has an additive effect on purchase motivation; 
the purchase of products means that consumers are trying to maintain their ideal self-image. The perception of brand suitability is the strongest predictor of the influencing of brand loyalty (Liu \& Li, 2012). A study conducted by Yoo and Park (2016) found that self-suitability also affected brand preference, brand choice and brand loyalty, and that the suitability of self-image that matches the product may be an essential factor which affects satisfaction. Khalid et al. (2018) found that the theory of self-conformity affected consumer purchase intentions of cosmetic products. Muslim consumers with a high level of religiosity tend to have such intentions for products that meet halal certification. In contrast, consumers who are concerned about the environment tend to choose environmentally friendly cosmetic products.

\section{Expectation Theory and Confirmation}

This paper also connects the theory of expectations and disconfirmation with the idea of disappointment. This theory explicitly explains the difference between positive and negative disconfirmation conditions. Positive disconfirmation tends to be related to feelings of pleasure, while negative disconfirmation is more likely to be associated with emotions and disappointment (Homburg \& Wayne, 2005). According to Oliver (1977), from the managerial aspect this theory explains postpurchase or post-adoption satisfaction as a function of expectations. Consumers' expectations or expectations are indeed very diverse, depending on their characteristics when evaluating a product or service. Hui and Alvin (2007) explain that different consumer groups divided based on geographical segmentation have different preferences and expectations in terms of the effect of consumer satisfaction even though on the same object, namely tourist visits to Singapore. The relevance of theory and empirical studies in the field of marketing still exists. This paper proposes that the idea of expectations and disconfirmation is still very relevant in explaining consumer post-purchase behaviour related to satisfaction to the consequences of consumer satisfaction.

\subsection{Previous Studies}

\section{Functional, Symbolic, and Hedonic Value of the Perceptions of Customer Satisfaction}

Previous studies in this field have mainly explained the overall relationship between perceived value and post-purchase consumer behaviour. In this case, the functional value includes tangible, for example the dishes or food served in a restaurant, and intangible aspects, including the atmosphere, decoration concept and services provided (Yang\& Mattila, 2016). Demirgunes (2015) states that perceived functional value is the most important dimension that can affect consumer satisfaction with a product. In addition, Yoo and Park (2016) translate functional value as usefulness value, which indicates that consumer satisfaction is in the context of choosing a gift shop . Eid and Gohary (2015) conducted a study of Muslim consumer respondents and noted that functional value has a strong influence on consumer satisfaction with the services used. In the context of fine dining restaurants, which are closely related to the impression of hedonism, 
functional value is one of those that most influences satisfaction. The reason for this is that value has a principle of benefit from the products and services received. Based on this explanation, it is hypothesised that the perceived functional value of consumers has a positive effect on Muslim consumer satisfaction (H1).

Perceived symbolic value is the consumer's psychological attachment to a product and is associated with self-image and identity (Smith \& Colgate, 2007). Eid and Ghohary (2015) state that symbolic value is a perceived social value, while Yoo and Park (2016) explain the relationship between symbolic value and consumer satisfaction using the self-congruity theory developed by Sirgy (1985). The theory states that self-conformity is related to self-image, and has an additive effect on purchase motivation; the purchase of a product means that consumers are trying to maintain their ideal self-image. Sirgy et al. (2016) researched the context of shopping behaviour, finding that the value of self-expression had a positive influence on consumer satisfaction related to behaviour. In line with these findings, Bosnjak et al. (2014) found that self-expression had a positive effect on personal pleasure, as affective elements (emotion and social recognition) play a fundamental role and contribute to consumer satisfaction (Holbrook \& Havlena, 1986). Therefore, consumers do not only consider values related to a rational point of view, but are also influenced by emotional aspects and the need for social recognition. When consumers feel that a chosen product or service will represent their image, customer satisfaction will emerge as a consequence of the fulfilment of this symbolic value. Therefore, we propose that the symbolic value perceived by consumers has a positive effect on Muslim consumer satisfaction (H2).

Consumers do not only see things from a rational point of view by only considering the usefulness of a product or service. According to Hirschman and Hoolbrook (1982), intrinsic human behaviour tends to seek pleasure and enjoyment. Meanwhile, the perceived hedonic value is closely related to the context of a luxury product or service. Hirschman and Holbrook state that hedonic consumption is behaviour related to multi-senses, including the fulfilment of consumer pleasures, fantasies, and passion when choosing a product or service. This value measures the services provided by restaurants to please consumers. In other terms, perceived hedonic value is also referred to as perceived emotional value, because hedonism is part of the affective factors that can affect customer satisfaction (Dumand \& Mattila, 2005). Ryu et al. (2010) argue that the perceived hedonic value has a positive effect on behavioural intention and customer satisfaction, while Yoo and Park (2016) also explain that consumer satisfaction with a product that provides mass-customisation services is influenced by perceived hedonic value. Based on this, it is posited that perceived hedonic value has a positive effect on customer satisfaction (H3).

\section{Perceived Islamic Values in Consumer Satisfaction}

Perceived Islamic value cannot be generalised to consumer categories from other cultural backgrounds, so there have been few studies which examine the causal relationship between the perceived Islamic value construct and other constructs in the field of marketing. Perceived Islamic value is the value perceived by Muslim consumers when choosing products or services based on Islamic values and rules. 
In this case, it is not limited to halal, or not because halal is already a mandatory issue for Muslims. All aspects of services provided are related to worship facilities etc. which are compatible with Islamic law (El-Adly \& Eid, 2017). Eid (2013) states that the Islamic value inherent in tourism services can provide satisfaction for Muslim consumers, while Eid and Gohary (2015) state that perceived Islamic values influence Muslim consumer satisfaction with services. Siala (2013) found that Muslim consumers tend to display religiocentrist behaviour when products and services offered conform to the beliefs they hold and can thus form loyalty. Muslim consumers have specific criteria for choosing products or services, based on their fundamental religious beliefs. For example, in the context of a restaurant, certainty about whether dishes are halal and the availability of places of worship may be necessary for Muslim consumers, because these elements are related to their principles. Therefore, we hypothesise that perceived Islamic value has a positive effect on Muslim consumer satisfaction (H4).

\section{Customer Satisfaction on Willingness to Pay More}

Customer satisfaction is one of the critical indicators for assessing the performance of a business (Dahl \& Jimmy, 2015). It is an evaluation made by consumers of a product or service to assess whether it meets their expectations (Kotler \& Keller, 2016). The results of such evaluation have an impact on consumers' post-purchase behaviour. Homburg and Wayne (2005) state that willingness to pay is more a consequence of the form of consumer satisfaction. In the category of premium products or services, consumers tend to be irrational in their decision making. Luo and Christian (2007) argue that consumer satisfaction determines the efficiency of future company promotions, the emergence of loyal behaviour and the willingness to pay more. Siala (2013) states that the attitude of loyalty expressed in satisfaction with purchases in the past forms tolerance towards prices. When a product meets the expectations of consumers, they also tend to be tolerant (insensitive) to price. Therefore, it is proposed that customer satisfaction has a positive effect on the willingness to pay more. (H5)

\section{The Moderating Role of Religiosity}

Religion is an important cultural factor because it is one of the most universal and has a significant effect on people's attitudes, values, and behaviour, at both the individual and community level (Mokhlis, 2009). Religiosity is an essential issue in this study because religion is the main reason for Muslim consumers to make particular decisions (Alam and Hisam, 2011). They tend to pay attention to what is prohibited and allowed in Islam in their consumption patterns. Religiosity acts as a moderating variable. Variation in the level of religiosity will affect the relationship between several perceived values and Muslim consumer satisfaction. Hamzah et al. (2014) conducted a study on adolescent hedonic behaviour in Malaysia, finding that the relationship between religiosity and hedonic behaviour produced negative and significant results. The higher the level of one's religiosity, the lower one's hedonic behaviour. The same was found by Karaduman (2016), who stated that religious rules were negatively related to hedonic consumption 
in consumer groups in a country. Therefore, we posit that religiosity can weaken the influence of perceived hedonic value on Muslim consumer satisfaction (H6).

Materialist value is a person's belief related to ownership of something which is a symbol of social status (Agarwala, Mirsha, \& Singh, 2018). The value of religiosity is negatively related to the level of materialism that is oriented towards pleasure and desire. From an Islamic point of view, the materialistic nature leads to a Riya nature. Rasulullah SAW once said that "Whoever leaves luxurious clothes because of tawadhu to Allah, even though he can afford them, Allah will call him on the Day of Resurrection all humans to be asked to choose their clothes" (HR. Attirmidzi). Therefore, it is proposed that the value of moderate religiosity (weakens ) the effect of perceived hedonic value on customer satisfaction (H7)

Gayatri and Margee (2005) state that the upholding of Islamic values by Muslim consumers will influence their evaluation of hotels, restaurants and flight services, while Eid (2015) argues that consumers with high religiosity tend to pay attention to the perceived value of Islam in evaluating their satisfaction. O'Cass et al. (2013) state that the religiosity of a consumer will reduce any "antagonistic " influence. Consumer religiosity will then weaken consumption based on consumer status. The assumption regarding religiosity influences consumers' evaluation of a service. Taylor et al. (2017) stated that the existence of a religious symbol could increase positive perceptions for consumers with a higher level of religiosity. Consumers with such a level will tend to focus on perceived Islamic values. The higher the story of one's religiosity, the higher the sensitivity to matters relating to conformity with Islamic religious values. It is therefore hypothesised that the value of religiosity positively moderates (strengthens) the effect of perceived Islamic value on customer satisfaction (H8).

\subsection{Conceptual Framework}

Figure 1 illustrates the model and corresponding hypotheses. The study will focus on the four dimensions of perceived value (perceived functional value, perceived symbolic value, perceived hedonic value, and perceived Islamic value). The first step is to examine the influence of these four dimensions $(\mathrm{H} 1, \mathrm{H} 2, \mathrm{H} 3, \mathrm{H} 4)$ on consumer satisfaction and to assess the link between consumer satisfaction and the willingness to pay more. In the second step, we examine $\mathrm{H} 2, \mathrm{H} 3$, and $\mathrm{H} 4$ with religiosity as a moderator (with interaction ). The method will be explained in more detail in the following section. 


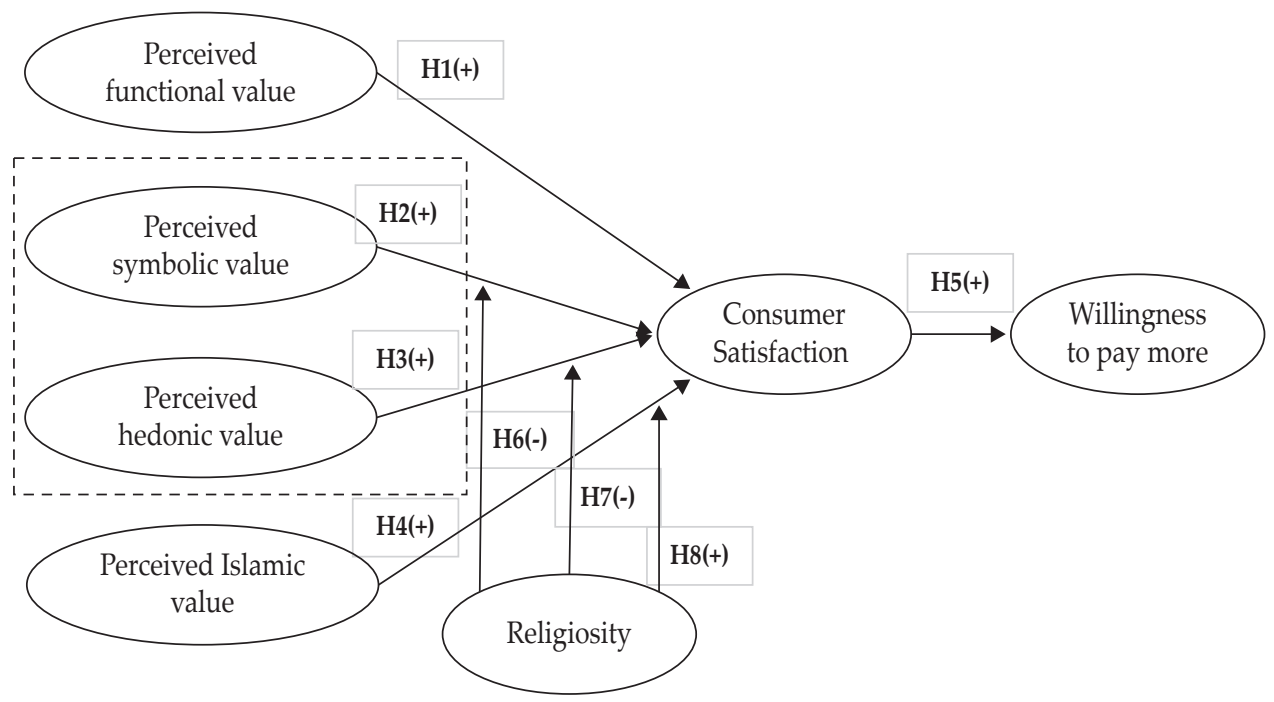

Based on: Yang and Mattila (2016); Peng and Cheng (2018); Eid (2013); Pham and Ahammad (2017)

Figure 1.

Research Model

\section{METHODOLOGY}

\subsection{Data}

Determination of the study sample considered the unit of analysis, namely the consumer. The number of samples in the study included minimum coverage of the sample size, namely the number of observations multiplied by five (Hair et al., 2014, p.100 ). The study has 22 observation items, so the minimum sample size is 110. According to Hair (2014) that if the sample size is too large, then the method becomes very sensitive, so it is difficult to obtain acceptable goodness-offit measures. The minimum sample size is $5-10$ observations for each parameter estimated and a total of 281 respondents completed the questionnaire. The sampling technique used was purposive sampling, based on predetermined criteria according to the research needs (Cooper \& Schindler, 2014, p.152). The consumers in this study were Muslims who had used or enjoyed luxury restaurant services. The research identified post-purchase behaviour and Muslim consumer behaviour, but did not include all exclusive restaurants nationwide, instead taking a sample of restaurants in four major cities in Indonesia (Surabaya, Jogja, Malang and Jakarta). The four cities represented Muslim consumers in the country, considering that more than half of the population lives on the island of Java. The sample did not include Muslim babies or children who were still unable to speak and write, as the research wanted to capture perceived value based on the logic and knowledge owned by adults. If children go to fine dining restaurants it may be because of invitations from parents. 


\subsection{Model Development}

The researcher used two-step estimation; in the first step, it was necessary to estimate the structural model without including the effect of the interaction. The estimation results in the first stage as the basis for calculating the factor load value of the interaction variable and the error variance value for the single indicator of the interaction variable. After the calculation, the second step added the interaction variable with one needle in the previous model. The interaction factor load value and error variance were included in the added interaction variables. Table 2 shows the measurement model. Discriminant validity was tested by the correlation between the variables.

Table 1.

Measurement Scale

\begin{tabular}{|c|c|}
\hline Item & Reference Models \\
\hline Perceived functional value & Adapted from Peng and Cheng (2018) \\
\hline Perceived symbolic value & Yoo and Park (2016); Peng and Cheng (2018) \\
\hline Perceived hedonic value & Yang and Mattila (2016) \\
\hline Perceived Islamic value & Eid (2013); El-Adly and Eid (2017); Maulan and Maisarah (2016) \\
\hline Religiosity & Worthingthon (2003) \\
\hline Consumer Satisfaction & Eid and Gohary (2015); Yoo and Park (2016) \\
\hline Willingness to pay more & Ligas and Arjun (2012); Pham and Ahammad (2017) \\
\hline
\end{tabular}

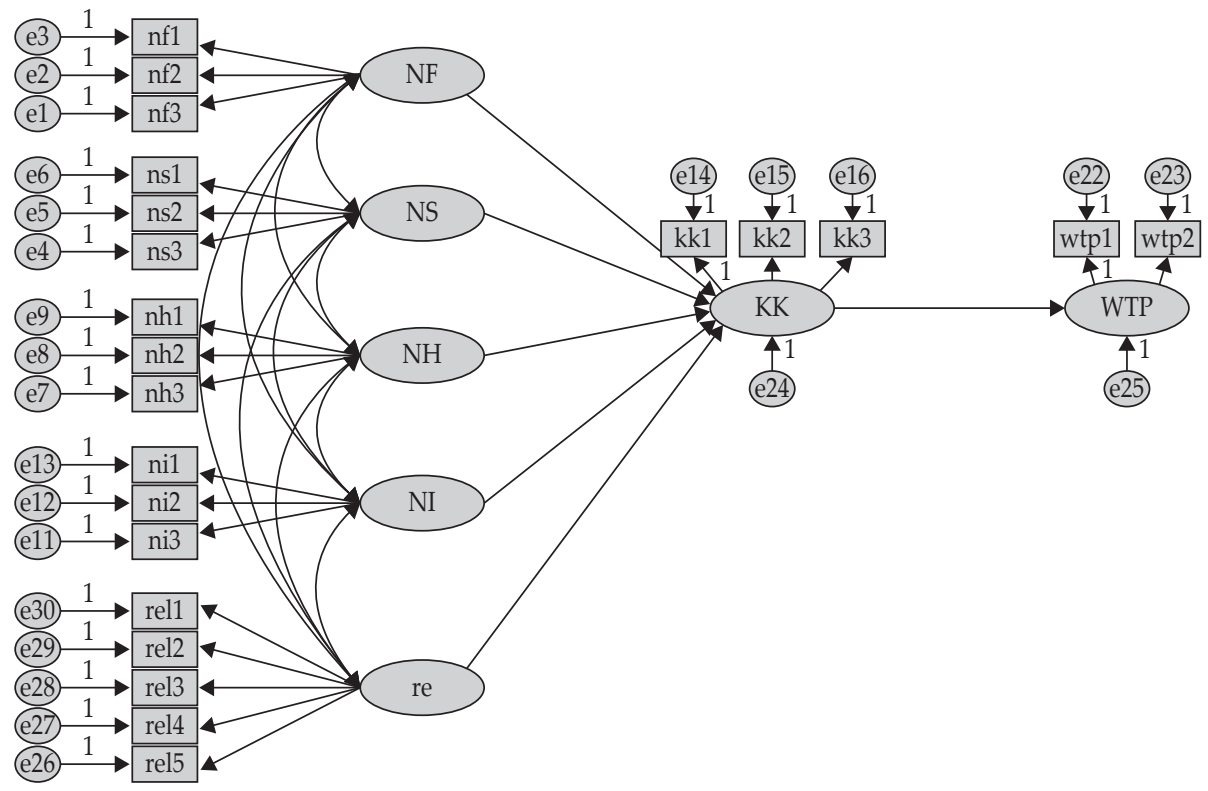

Source: Data Processing Results.

Figure 2.

Structural Model without Interaction Estimation 
The estimation results in the first stage of the structural model without interaction estimation (Figure 2) were used to calculate the factor load value of the interaction variable and the error variance value for the single interaction variable indicator.

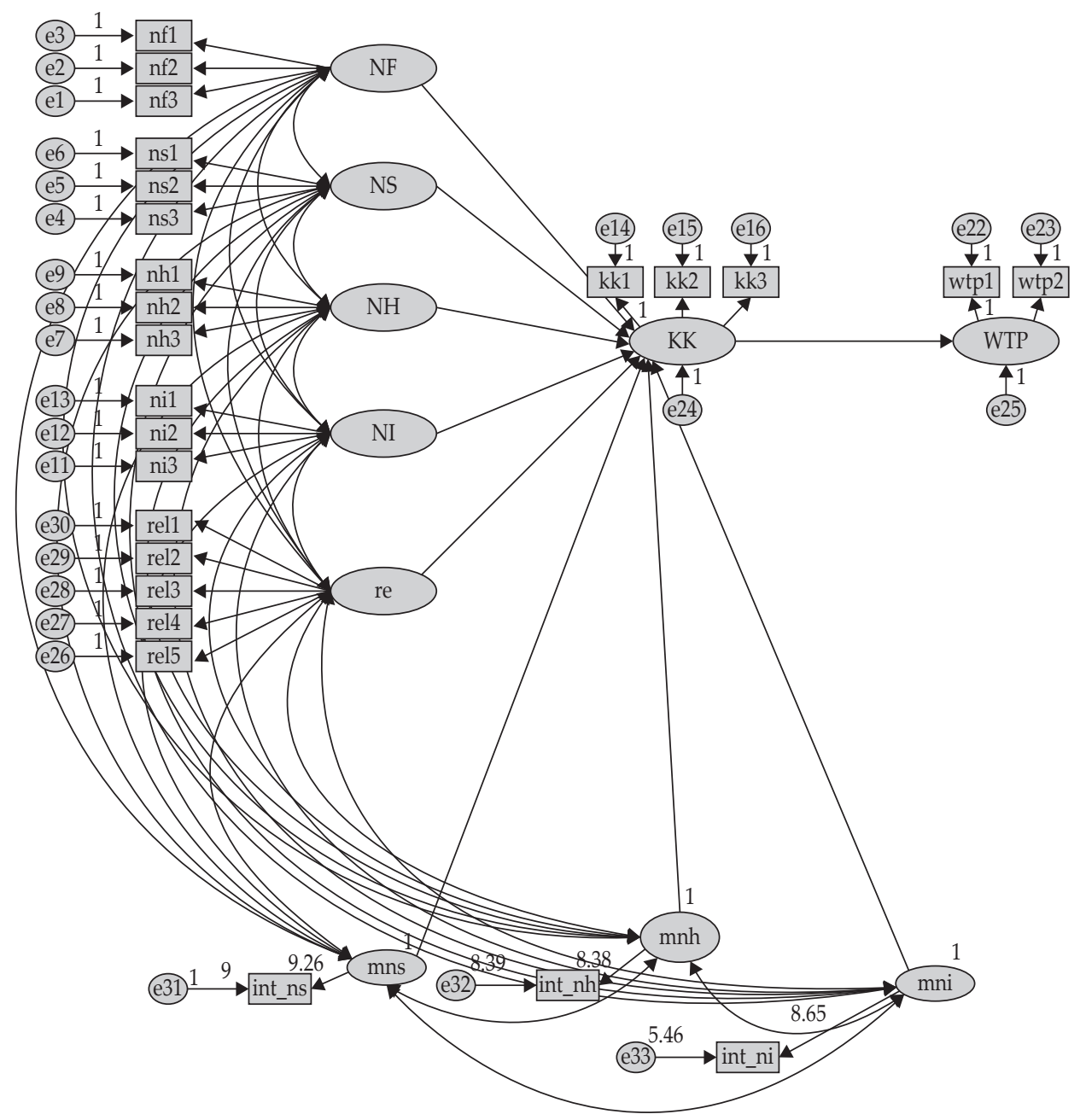

Source: Data Processing Results.

Figure 3.

Structural Model with Interaction Estimation

The next step was to add the interaction variable with one indicator in the previous model (Figure 3). The interaction factor load value and error variance were included in the added interaction variables. Analysis was then conducted to estimate the interaction effect. In this study, the three effects of moderating interaction were analysed simultaneously so that they could better represent the research model that had been built. 


\subsection{Method}

The survey instrument was a self-administered questionnaire that was distributed either directly, via email, or through a survey site (web survey ), to facilitate accessibility and increase respondent participation (Cooper \& Schindler, 2014, p.225 ). Technically, several questions functioned as screening responders, such as "Have you ever been to a restaurant with a fine-dining concept?", "How often do you go to restaurants with a fine-dining concept?" "What is your goal for going to a restaurant with a fine-dining concept?" The research used the question "Among these restaurants, which restaurant have you been to?" to confirm that the participants understood the context of the research.

Likert scale measures were employed for each statement, ranging from $1=$ strongly disagree to $5=$ strongly agree (see Table 2 ). Statement items used indirect words to minimise the emergence of social desirability bias and so that the results would provide an accurate picture. Religiosity is a sensitive issue to discuss. The possibility of increasing social desirability bias depends on the situation at hand if the case is considered unethical (Chung \& Monroe, 2003). Based on these arguments, the use of indirect sentences with a third person subject in the questionnaire was intended to minimise social desirability bias. The questionnaire consisted of 25 statement items that were compiled based on the literature review of previous studies. The data analysis method was structural equation modelling (SEM), namely CB-SEM. CB-SEM was used because the sample size was relatively large, and the data characteristics fulfilled the CB-SEM assumption; that is, they were normally distributed. This model demands a robust theoretical basis so that the method will be feasible for use in academic testing and justify the testing conducted with complex analysis (Ghozali \& Latan, 2015, p.19).

The research tested the hypotheses by observing the path coefficient value and significance value ( $p$-value). A positive path coefficient value indicates that the independent variable is positively related to the dependent one. In contrast, a negative coefficient value indicates that the independent variable is negatively related to the dependent variable. This study used the SEM analysis method with the aid of the IBM AMOS 24 program. The SEM method can measure variables that are able to be measured, or variables that cannot be measured (latent variables) (Hair et al. 2014, p.546). The tests conducted in the analysis employed two types of application, namely IBM SPSS 20 and IBM AMOS 24. Table 2 provides a summary of the goodness-of-fit statistics indicator. Figures 2 and 3 show the structural equation modelling results specified in the AMOS 24.0 output. The results relating to the fit of the structural model generally support the claim of good fit. 
Table 2.

Summary of the Goodness-of-fit Statistics Indicator

\begin{tabular}{lcc}
\hline Type & Index & Recommended Value \\
\hline Goodness of Fit Model & Goodness of Fit Model & \\
Absolute fit measures & Chi square statistic $(\chi 2)$ & Small \\
& P & $\geq 0.05$ \\
& GFI & $\leq 0.90$ \\
& RMSEA & $\leq 0.08$ \\
Incremental fit measures & Normed $\chi 2$ (CMIN/df) & $2 \leq$ Normed X2 $\leq 5$ \\
Parsimonious fit measures & CFI & $\geq 0.90$ \\
\hline
\end{tabular}

Source: Hair et al. (2014, pp.577-581)

\section{RESULTS AND ANALYSIS}

\subsection{Results}

Table 3 (statistical descriptives) shows that the respondents indicated that there were variations in their answers related to completing the questionnaire. The NF variable has a mean value of 4.23 , indicating that the participants agreed that the fine dining restaurant that they had been to in the last six months had an aesthetic atmosphere, unique (delicious) dishes and provided friendly service. The NS variable with a mean result of respondents' answers of 3.42 shows that consumers or respondents tended to be neutral, because going to fine dining restaurants is considered to be a symbol of social status and can be used as a way to communicate their identity. Furthermore, the perceived hedonic value variable, with a mean value of 3.84, shows that Muslim consumers or respondents agreed that the fine dining restaurant they had been to in the last six months had given them pleasure and pampered consumers with various services.

The Islamic value variable has a mean of 4.28 , indicating that Muslim consumers agreed that a restaurant that provides services or dishes is not considered to be contrary to Islamic law norms. The KK variable of 3.78 shows that the consumers were happy with their decision to have gone to such a fine dining restaurant. Religiosity has a mean of 4.42, indicating that respondents agreed or strongly agreed that religion provides meaning and is used as a basis for life goals. The willingness to pay more (WTP) variable, with a mean value of 3.34, shows that consumers tended to be neutral about the related statements. They would go to the restaurant again even if the prices were higher than other restaurants and they were willing to pay the extra amount. 
Table 3.

Statistic Descriptives

\begin{tabular}{|c|c|c|c|c|}
\hline Variable(s) & Item(s) & $\begin{array}{c}\text { Standard } \\
\text { Deviation }\end{array}$ & $\begin{array}{c}\text { Mean } \\
\text { Indicator }\end{array}$ & $\begin{array}{c}\text { Mean } \\
\text { Variable }\end{array}$ \\
\hline \multirow{3}{*}{$\begin{array}{l}\text { Perceived Functional } \\
\text { Value (NF) }\end{array}$} & NF1: Atmosphere & 0,655 & 4,331 & \multirow{3}{*}{4,23} \\
\hline & NF2: Meal & 0,753 & 4,145 & \\
\hline & NF3: Service & 0,735 & 4,227 & \\
\hline \multirow{3}{*}{$\begin{array}{l}\text { Perceived Symbolic } \\
\text { Value (NS) }\end{array}$} & NS1: Social Status & 0,944 & 3,622 & \multirow{3}{*}{3,42} \\
\hline & NS2: Self-Image & 0,948 & 3,352 & \\
\hline & NS3: Self-Identity & 0,927 & 3,298 & \\
\hline \multirow{3}{*}{$\begin{array}{l}\text { Perceived Hedonic } \\
\text { Value (NH) }\end{array}$} & NH1: Enjoyment & 0,837 & 3,953 & \multirow{3}{*}{3,84} \\
\hline & NH2: Happiness & 0,895 & 3,736 & \\
\hline & NH3: Being pampered & 0,932 & 3,85 & \\
\hline \multirow{3}{*}{$\begin{array}{l}\text { Perceived Islamic } \\
\text { Value (NI) }\end{array}$} & NI1: Ease of worship & 0,729 & 4,266 & \multirow{3}{*}{4,28} \\
\hline & NI2: Halal food & 0,724 & 4,363 & \\
\hline & NI3: No element of sensuality & 0,751 & 4,22 & \\
\hline \multirow{3}{*}{$\begin{array}{l}\text { Consumer } \\
\text { Satisfaction (KK) }\end{array}$} & KK1: Pleasure in choosing & 0,753 & 3,996 & \multirow{3}{*}{3,78} \\
\hline & KK2: Wise option & 0,81 & 3,48 & \\
\hline & KK3: Right choice & 0,798 & 3,875 & \\
\hline \multirow{5}{*}{ Religiosity (RE) } & RE 1: Religion as a purpose & 0,843 & 4,366 & \multirow{5}{*}{4,42} \\
\hline & RE 2: Leisure time & 0,767 & 4,266 & \\
\hline & RE 3: Self-introspection & 0,725 & 4,441 & \\
\hline & RE 4: Mean & 0,628 & 4,58 & \\
\hline & RE 5: Influence in life & 0,687 & 4,494 & \\
\hline \multirow{2}{*}{$\begin{array}{l}\text { Willingness to Pay } \\
\text { More (WTP) }\end{array}$} & WTP1: Return visit & 0,9 & 3,43 & \multirow{2}{*}{3,34} \\
\hline & WTP2: Price sensitivity & 0,871 & 3,263 & \\
\hline
\end{tabular}

As shown in Table 4 (without interaction) and Table 5 (with interaction), all the indices fall within the recommended ranges, thus supporting the claim of a good fit for the model. In particular, the value of the normed chi-square (CMIN/df) is 1.755 (without interaction) and 1.803 (with interaction), which means that the proposed model has the correct level of conformity because the expected value is $\leq 2$ and can still be accepted up to $\leq 5$ (Hair et al. (2014), which represents a good fit. The values of the chi-square $\left(X^{2}\right)$ and $p$-value $(0,000)$ are 338,793 (without interaction) and 434,405 (with interaction), with the smaller values being considered more representative of the theoretical model with the actual situation (Hair et al. (2014). Overall, this research is acceptable as the theoretical model and the reality do not have too high a value.

The RMSEA values are 0.052 (without interaction) and 0.054 (with interaction), which are below the recommended maximum of 0.080 suggested by Hair et al. (2014, p.579), and also suggest that the measurement model fits well. The GFI values are 0.903 (without interaction) and 40.890 (with interaction), and the AGFI values of 0.872 (without interaction) and 0.852 (with interaction) are both above the 0.900 level recommended by Hair et al. (2014, p.579). The research also used CFI to measure the goodness-of-fit of the models. The CFI index values of 0.945 (without interaction) and 0.970 (with interaction) for the measurement model both exceed the recommended level of 0.900 (Hair et al., 2014, p.580). From all of the 
values outlined above, it can be inferred that the structural model represents an acceptable fit.

Table 4.

Goodness of Fit Structural Model without Interaction Estimates

\begin{tabular}{lcc}
\hline Goodness of Fit & Results & Criteria \\
\hline Chi Square & 338,793 & As small as possible \\
Normed Chi Square (Cmin/df) & 1,755 & $2 \leq$ Normed $\chi 2 \leq 5$ \\
RMSEA & 0,052 & $0,03 \leq$ RMSEA $\leq 0,08$ \\
CFI & 0,945 & $\geq 0,90$ \\
AGFI & 0,872 & $\geq 0,90$ \\
GFI & 0,903 & $\geq 0,90$ \\
\hline
\end{tabular}

Table 5.

Goodness of Fit Structural Model with Interaction Estimates

\begin{tabular}{lcc}
\hline Goodness of fit & Results & Criteria \\
\hline Chi Square & 434,405 & As small as possible \\
Normed Chi Square (Cmin/df) & 1,803 & $2 \leq$ Normed $\chi 2 \leq 5$ \\
RMSEA & 0,054 & $0,03 \leq$ RMSEA $\leq 0,08$ \\
CFI & 0,970 & $\geq 0,90$ \\
AGFI & 0,852 & $\geq 0,90$ \\
GFI & 0,890 & $\geq 0,90$ \\
\hline
\end{tabular}

Cronbach's $\alpha$ was used to investigate each construct's reliability; all the $\alpha$ coefficients achieved a value of at least 0.70 . The dimensions of perceived value had the following values: functional value 0.77 , symbolic value 0.82 , hedonic value 0.76 , and Islamic value 0.77 . The other constructs in the model had the following values: customer satisfaction 0.80 , willingness to pay more 0.81 , and religiosity 0.90 . The resulting scales were thus acceptable and sufficiently reliable (Hair et al., 2014, p.619). The factor loadings $(\lambda)$ were all higher than 0.61 and the AVE for the constructs ranged from 0.52 to 0.68 , so were all greater than the 0.50 threshold recommended by Hair et al. (2014, pp.618-619). The AVE for each construct was also greater than the squared correlation coefficient between the factors, thus demonstrating discriminant validity. In order to ensure the adequacy of the measurement model, the discriminant validity was tested by the correlation between the variables in the confirmatory model; the results show an acceptable level of discrimination (Table 5), as they were no higher than 0.8 (Hair et al., 2014, p.620). 
Table 6.

\section{Convergent and Discriminant Validities of the Measures}

\begin{tabular}{lccccccc}
\hline Construct & [1] & [2] & [3] & [4] & [5] & [6] & [7] \\
\hline Functional Value [1] & 0,53 & & & & & & \\
Symbolic Value [2] & 0,15 & 0,61 & & & & & \\
Hedonic Value [3] & 0,17 & 0,14 & 0,52 & & & & \\
Islamic Value [4] & 0,11 & 0,05 & 0,11 & 0,53 & & & \\
Customer Satisfaction [5] & 0,29 & 0,16 & 0,35 & 0,16 & 0,57 & & \\
Willingness to Pay More [6] & 0,20 & 0,05 & 0,05 & 0,22 & 0,11 & 0,63 & \\
Religiosity [7] & 0,13 & 0,06 & 0,20 & 0,02 & 0,29 & 0,04 & 0,68 \\
\hline
\end{tabular}

SEM was employed because it examines the relationship between complex variables and the variables tested are a type of latent variable. To test the hypotheses, a structural equation model was used (Hair et al., 2014). All the measurements of the equations were statistically significant at significance levels of 0.05 and 0.10 . Turning to the hypothesis testing, the results show that perceived functional value (0.303, po 0.00), perceived hedonic value $(0.35$, po 0.00$)$, and perceived Islamic value (0.136, po 0.05) significantly impacted customer satisfaction, thereby supporting $\mathrm{H} 1, \mathrm{H} 3$, and H4. Customer satisfaction (0.55, po 0.00) significantly impacted customer satisfaction, thereby supporting H5. The impact of perceived symbolic value, hedonic value, and Islamic value on customer satisfaction, with religiosity as a moderator, shows that only perceived Islamic value $(0.003$, po 0.085$)$ had a significant positive influence on customer satisfaction. Meanwhile, the impact of perceived symbolic value $(0.001$, po 0.398$)$ and perceived hedonic value $(0.01$, po $0.00)$ with interaction were not supported. These results are further discussed in the following section. The Amos output is presented in Figure 4.

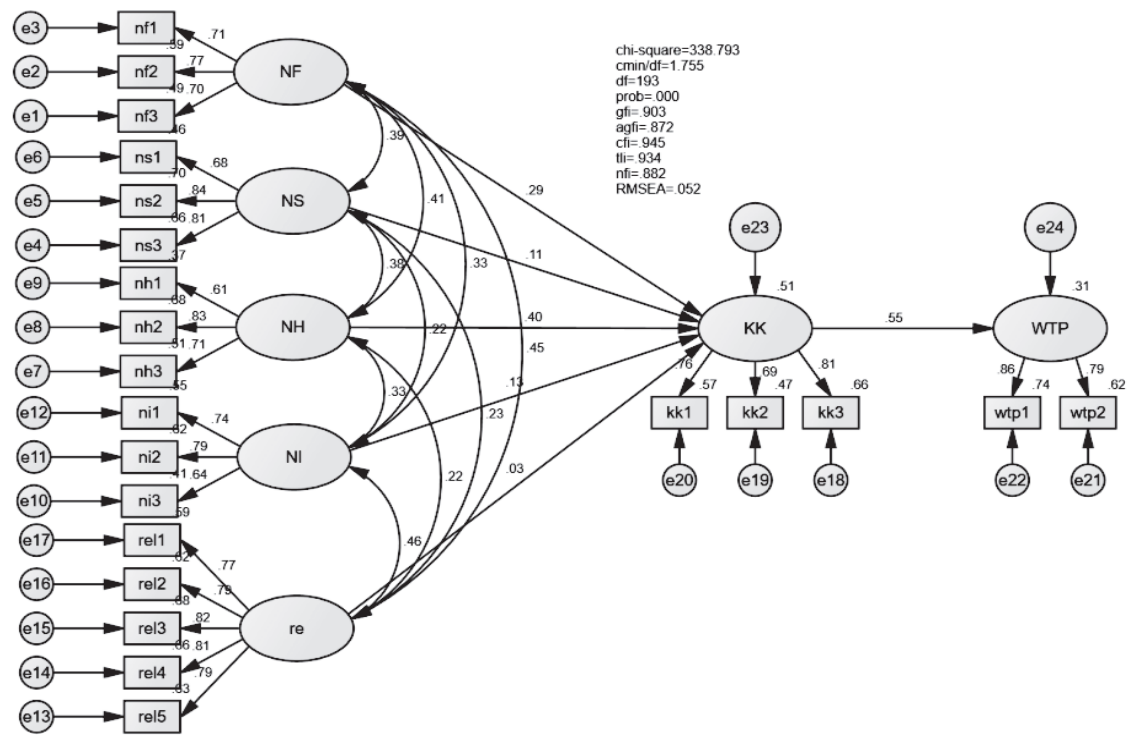

Source: Data Processing Results.

Figure 4.

Structural Model (AMOS Output) 


\subsection{Analysis}

The study findings have important implications from the dual standpoint of theory and practice. The first part of the study assessed the impact of perceived functional value, perceived symbolic value, perceived hedonic value, and perceived Islamic value on customer satisfaction, and the impact of customer satisfaction on willingness to pay more. Generally, all of the perceived values, including the functional, hedonic, and Islamic, influenced the customer satisfaction of our sample. Insignificant links were found between perceived symbolic value and customer satisfaction.

Moreover, perceived functional value had the most significant influence of four perceived value dimensions. This included tangible and intangible aspects, with real aspects related to the dishes or food served in the restaurants. In contrast, intangible factors included the atmosphere, decoration and services provided by the restaurant (Yang \& Mattila, 2016). Previous studies have found that perceived functional value is the most important dimension that can influence consumer satisfaction with products, which means that when perceptions regarding the benefits and usefulness of a product or service increase, consumer expectations regarding that aspect will also be high, so consumer satisfaction will also tend to increase (Demirgunes, 2015). In the context of fine dining restaurant service, consumers tend to have expectations related to the quality of service and dishes served in line with the definition of fine dining. Expectations related to service quality and unique dishes are also supported by the image of fine dining restaurants, with luxurious and elegant characteristics, so diners have expectations that are more related to the benefits obtained. Sheth et al. (1991) state that consumer expectations of the benefits of a product or service will tend to be higher for products or services with a superior or exclusive impression.

The second perceived value relates to symbolic value. The results of this study contradict those of Sirgy et al. (2016), who researched the context of shopping behaviour and found that the value of self-expression had a positive influence on consumer satisfaction related to such behaviour. In line with these findings, Bosnjak et al. (2014), who researched the field of sport tourism, demonstrated that self-expression had a positive effect on personal pleasure. This occurs because affective elements (emotion and social recognition) play a fundamental role and contribute to consumer satisfaction (Holbrook \& Havlena, 1986). The opinion of Eid (2015) is that social values have a positive influence on customer satisfaction. The result of perceived symbolic value on customer satisfaction is considered to have no significant effect. This means that consumer satisfaction with fine dining restaurant services is not influenced by symbolic motives or is related to social recognition and the delivery of self-identity. The research context is not products, but services that have intangible properties; the influence of symbolic value on consumer satisfaction will tend to have a significant effect in the product context because consumers will be able to display something more tangible (Yang \& Mattila, 2016).

The need for social recognition or symbolic value perceived by consumers is more significant in the context of products because the display of social status seems more real when consumers use certain products (Yang \& Mattila, 2016). Based on this explanation, post-purchase evaluation is not influenced by the ability 
of services to support consumers' social status. In addition, we suspect that this perceived symbolic value has a negative meaning or connotation for respondents who are Muslim consumers. Therefore, statements on the questionnaire relating to social recognition could be interpreted negatively by the respondents; for example, being arrogance, evaluation related to social bias is also carried out in this variable . Researchers have concerns that consumers will tend to look more, so they use a third person in the survey related to this variable.

The third perceived value is hedonic value, which refers to emotional benefits such as pleasure. Products can create pleasant experiences and feelings for customers (Dubois \& Laurent 1994; Yang \& Mattila, 2016). In line with this, Park (2004) states that hedonic value is associated with enjoyment and joy when consumers eat at a luxury restaurant. It also confirms $\mathrm{H} 3$, that the satisfaction of the post-purchase evaluation of consumers considers the extent to which a restaurant can provide a pleasant experience in the form of entertainment. In the digital era, with the very rapid development of social media, consumers can easily find recommendations for restaurants, complete with location and ratings. It is therefore not uncommon for people to go to restaurants based on the purpose of looking for entertainment and pleasure, considering that restaurants with fine dining concepts are usually visited in opportunity and specific tempo. The results of this study are in line with the findings of Dumand and Mattila (2005) perceived emotional value because hedonism is one of the affective factors that can affect consumer satisfaction. Eid and Gohary (2015) stated that perceived personal value, which is also mentioned as significant value .

The fourth perceived value is Islamic value. In the context of tourism, Eid (2013) argues that Muslim consumers have a special dimension in the perceived value construct and believes that religious identity appears to play an important role in shaping the consumption experience, including hospitality and tourism choices among Muslim customers. It is obligatory for all Muslims to consume products that are permitted by Allah SWT and are under the jurisdiction of the Shari'a. Muslim consumer satisfaction is significantly affected by their evaluation of the extent to which restaurants provide services that are considered to be in accordance with Islamic law; for example, by providing halal dishes and places of worship, and not displaying images that contain elements of sensuality or pornography. These results also support the findings of previous research in the service context, that perceived Islamic value has a significant effect on Muslim consumers' satisfaction (Eid, 2013; Eid \& Gohary, 2015). The findings by Siala (2013) indicate that Muslim consumers tend to be religious, which means that when the products and services offered conform to the beliefs they embrace, this will create satisfaction and loyalty. Although the results of the study show findings that are in accordance with the hypothesis, perceived Islamic value is not the antecedent that has the most significant influence in shaping consumer satisfaction, as is evident from the research results that are classified as not being too high at the level of significance and estimation. Researchers suspect that because Indonesia has the largest number of Muslims in the world, industrial players have also adjusted the target market. In addition, based on discussions with experts, research objects that are not specific to sharia-based products or services also affect the research results. However, this is considered to be able to explain reality, because when the object 
of research is a sharia-based product or service, it is feared that the research results will tend to be predictable without conducting a survey process .

Hypothesis 5 concerns the effect of consumer satisfaction on the willingness to pay more. Willingness to pay is a measure of the value that a person gives to consumption or experiences in relation to satisfaction with products or use in monetary units (Homburg \& Wayne, 2005). This figure shows that customer satisfaction is an antecedent which has a significant influence on the willingness to pay more variable. These findings simultaneously confirm H5. The results of this study are in line with the findings of previous research, which suggest that willingness to pay is more a consequence of a form of consumer satisfaction, because consumers sometimes have limited rationality when consuming products or services (Homburg \& Wayne, 2005). Other studies have also explained that consumer satisfaction determines the efficiency of promotion by companies in the future, because when customers are satisfied, the tendency for loyal behaviour and greater willingness to pay will be higher (Luo \& Christian, 2007). Consumer satisfaction is still considered one of the main factors which influences the sustainability of a business (Dahl \& Jimmy , 2015). This is because the goal of a product or service provider can be said to be successful when it meets the expectations of consumers; when a consumer is satisfied with the product or service received, it is expected that their desire to repurchase will rise. Moreover, when consumer loyalty has begun to form based on past experiences of products or services, consumers will tend to become price insensitive (Siala, 2013).

Table 7 shows the results of the testing of hypotheses $\mathrm{H} 1-\mathrm{H} 5$.

Table 7.

Hypothesis Testing Results

\begin{tabular}{|c|c|c|c|c|c|}
\hline \multirow[b]{2}{*}{ Hypothesis } & \multirow[b]{2}{*}{ Variables } & \multirow{2}{*}{$\begin{array}{l}\text { Standardised } \\
\text { regression } \\
\text { weight }(\beta)\end{array}$} & \multicolumn{2}{|c|}{ Significancy } & \multirow[t]{2}{*}{ Hypothesis } \\
\hline & & & $P$ value & $\begin{array}{c}\text { Critical } \\
\text { Ratio }\end{array}$ & \\
\hline $\mathrm{H} 1\left(^{+}\right)$ & $\begin{array}{c}\text { Perceived } \\
\text { Functional Value } \\
\rightarrow \text { Customer } \\
\text { Satisfaction }\end{array}$ & 0,303 & 0,00 & 3,623 & Supported \\
\hline $\mathrm{H} 2(+)$ & $\begin{array}{c}\text { Perceived } \\
\text { Symbolic Value } \\
\rightarrow \text { Customer } \\
\text { Satisfaction }\end{array}$ & 0,076 & 0,20 & 1,268 & $\begin{array}{c}\text { Not } \\
\text { Supported }\end{array}$ \\
\hline $\mathrm{H} 3(+)$ & $\begin{array}{c}\text { Perceived } \\
\text { Hedonic Value } \\
\rightarrow \text { Customer } \\
\text { Satisfaction }\end{array}$ & 0,35 & 0,00 & 5,122 & Supported \\
\hline $\mathrm{H} 4(+)$ & $\begin{array}{c}\text { Perceived } \\
\text { Islamic value } \\
\rightarrow \text { Consumer } \\
\text { satisfaction }\end{array}$ & 0,136 & 0,05 & 1,949 & Supported \\
\hline $\mathrm{H} 5(+)$ & $\begin{array}{c}\text { Customer } \\
\text { Satisfaction } \rightarrow \\
\text { Willingness to } \\
\text { Pay More }\end{array}$ & 0,55 & 0,00 & 7,237 & Supported \\
\hline
\end{tabular}


This study also assesses the effect of perceived hedonic, symbolic, and Islamic value on customer satisfaction, with religiosity as a moderating variable. Symbolic value is related to the perceived value of consumers related to the ability of restaurants to support their social status, which, according to Agarwala, Mirsha, and Singh (2018), is related to the value of materialism. Hypothesis H6 proposes that the moderation mechanism of religiosity weakens the relationship between perceived symbolic value and consumer satisfaction. In the context of a fine dining restaurant, religiosity is not considered to have a significant moderating effect on the relationship between the two variables. The results of the analysis show that there is no significant difference between Muslim consumers with a high level of religiosity and those with a low level when evaluating resulting satisfaction. The ability of fine dining restaurant services is supporting their social status .

The results of this study can be explained from a different perspective, that of consumption related to the impression of luxury, both in the context of products and services. The element of religiosity does not play a big role in explaining this, and it is more greatly influenced by socio-psychological aspects (Nwankwo et al., 2014). The results of the study are also in line with the findings of Razzaq et al. (2018), who showed that the intrinsic religiosity aspect does not significantly moderate the relationship of hedonic shopping behaviour, which is also related to social recognition of Muslim consumer shopping behaviour in Pakistan. This explanation is also related to $\mathrm{H} 2$, which concerns the direct estimation of the effect of perceived symbolic value on consumer satisfaction. There is no significant effect, so the variables that can potentially moderate the relationship between the two relate to the socio-psychological aspect, not the religious.

Table 8.

Estimation Results of the Moderation Hypothesis

\begin{tabular}{|c|c|c|c|c|c|}
\hline \multirow[b]{2}{*}{ Hypothesis } & \multirow[b]{2}{*}{ Variables } & \multirow{2}{*}{$\begin{array}{c}\text { Standardized } \\
\text { regression weight } \\
(\beta)\end{array}$} & \multicolumn{2}{|c|}{ Significancy } & \multirow[b]{2}{*}{ Hypothesis } \\
\hline & & & P-value & $\begin{array}{c}\text { Critical } \\
\text { Ratio }\end{array}$ & \\
\hline H6 (-) & $\begin{array}{c}\text { Perceived } \\
\text { Symbolic Value } \\
\text { x Religiosity } \\
\rightarrow \text { Customer } \\
\text { Satisfaction } \\
\end{array}$ & 0,001 & 0,398 & 0,861 & Not Supported \\
\hline H7 (-) & $\begin{array}{c}\text { Perceived Hedonic } \\
\text { Value } x \text { Religiosity } \\
\rightarrow \text { Customer } \\
\text { Satisfaction } \\
\end{array}$ & 0,01 & 0,00 & 3,993 & Not Supported \\
\hline $\mathrm{H} 8(+)$ & $\begin{array}{c}\text { Perceived Islamic } \\
\text { Value x Religiosity } \\
\rightarrow \text { Customer } \\
\text { Satisfaction }\end{array}$ & 0,003 & 0,085 & 1,72 & Supported \\
\hline
\end{tabular}

Based on the results of the effect of the estimated interaction between perceived hedonic value and religiosity on customer satisfaction, the findings are interesting. It was estimated that religiosity negatively moderates (weakens) the effect of 
perceived hedonic value on consumer satisfaction. However, the estimation results show the opposite result, that the moderating role of religiosity is positive and significant, which means that it strengthens the effect. The estimation results could also imply that consumers with a high level of religiosity will tend to consider the hedonic aspect more when evaluating their satisfaction with fine dining restaurant services. It is suspected that the results of this study were caused by respondents considering that perceived hedonic value does not have the connotation of negative actions. In making this evaluation, the researcher refers to several items used to measure perceived hedonic value, including "I visit a fine dining restaurant to feel the pleasure offered by the restaurant", "Dining at a fine dining restaurant can give me joy", "Dining at a fine dining restaurant. fine dining restaurants for me can be used as a way to pamper myself". The statement items do not give an impression of negative behaviour; consumers assume that it is a common when visiting such restaurants to be pampered and to experience pleasure. In this literature, it can also be concluded that Islam does not prohibit its adherents from seeking pleasure or entertainment, but merely that religious obligations are not violated, and that aspects that are prohibited by the religion are not involved. Research by the Pew Research Center in 24 countries found that those with a higher level of religiosity tended to live more happily and enjoyed a better life (Hacket, Marshall, \& Schiller, 2019). This study is considered to be the basis for explaining that when consumers have a high level of religiosity, then the evaluation of their satisfaction is based more on the extent to which the restaurant visited only provides happiness and pleasure.

Religiosity can be said to positively moderate the effect of perceived Islamic value on customer satisfaction. Muslim consumers with a high level of religiosity consider the suitability of products or services in terms of Islamic aspects when evaluating their satisfaction with them (Eid \& Ghohary, 2015). The interaction between perceived Islamic value and religiosity has a significant influence in moderating the effect of such value on consumer satisfaction. If consumers have a high level of religiosity, the aspects of Islamic value attached to a product or service are one of the essential elements in evaluating their satisfaction. Taylor et al. (2017) state that the presence of a religious symbol attached to advertisements increases the positive perceptions of consumers with a higher level of religiosity. Researchers assume that the research context has a considerable influence on explaining it . Indonesia, with a large number of Muslim consumers, undoubtedly makes service providers consider matters related to Islamic aspects, such as providing halal food and prayer rooms. The following explanation is related to the context of the research, which is restaurant services considering that consumer visits to a restaurant .

\section{CONCLUSION AND RECOMMENDATIONS}

\subsection{Conclusion}

The results show that the influence of the four dimensions of perceived value in explaining customer satisfaction has a positive and significant effect, apart from the symbolic value variable, which is perceived to have an insignificant effect. The research context focuses on the service category, not products, so the effect 
of symbolic value is considered unable to explain consumer satisfaction with fine dining restaurant services. Symbolic value tends to be related to physical attributes (Yang \& Mattila, 2016); of the four dimensions, functional value has the most significant influence on consumer satisfaction. In line with previous studies, which have found that perceived functional value is the most critical dimension and has a strong influence. In influencing, consumer satisfaction with products or services (Demirgunes, 2015; Eid \& Gohary, 2015; Peng \& Cheng, 2018). With the criterion that respondents were limited to Muslim consumers, the results of the perceived Islamic value test also provide significant results regarding the influencing of consumer satisfaction, even though it is not the most robust predictor. The results prove that although the research was not conducted in the context of sharia-based products or services, Muslims in Indonesia still pay attention to the appropriateness of Islamic values attached to services, as an aspect that is considered when evaluating satisfaction. The effect of satisfaction on the willingness to pay more also produced a significant positive result with a high estimated value. Customer satisfaction is one of the strongest predictors of their willingness to pay more, which means that consumer sensitivity to prices tends to be low when they are satisfied with the service provided (Siala, 2013).

The paper also examined the moderating role of religiosity, with the results showing that it was not considered to moderate the effect of perceived symbolic value on consumer satisfaction. An interesting finding concerned the role of religiosity in moderating the effect of perceived hedonic value on consumer satisfaction, which shows that religiosity can strengthen the effect. This finding means that the higher the level of religiosity of consumers, the greater the extent that the evaluation of their satisfaction will centre on hedonic aspects. This is certainly contrary to the argument of the related hypothesis, which predicted a negative effect of moderating religiosity. Religiosity is also considered successful in moderating the effect of perceived Islamic value on consumer satisfaction. The more religious a person is, the higher their consideration of matters relating to religious beliefs, such as the provision of halal food and prayer rooms.

\subsection{Recommendations}

To provide excellent service quality, organisations should understand the patronage motives that drive consumers to go to their fine dining restaurant. As a result, understanding the value consumers perceive when evaluating fine dining restaurant service quality is the first step in providing a superior offering. With regard to Islamic people in Indonesia, organisations should understand what they have to do and give adequate service. Concerning the dimensions of perceived values, organisations can identify the stages of consumer satisfaction. Suppose the customer is at a perceived functional value stage (the dishes or food served in a restaurant; the atmosphere and decoration concept), the perceived hedonic value, and the perceived Islamic value (products or services based on Islamic values and rules ). In that case, it could enhance their satisfaction to make it behavioural, whereas if a customer is already behaviourally satisfied, it could further reduce their sensitivity to price. The study also found that if consumers have a high level 
of religiosity, aspects of Islamic value attached to a product or service are essential elements in evaluating their satisfaction.

For the majority of Muslim consumers, Indonesia ensures service providers consider matters related to Islamic aspects, such as providing halal food and prayer rooms. In order to build consumer satisfaction and the willingness to pay more, fine dining restaurants in Indonesia should improve several aspects, including the dishes or food served; intangible aspects such as the atmosphere, decoration and services provided; products and services based on Islamic values and rules; halal food; and prayer rooms . Based on the descriptive statistics of visitors who are vulnerable to $20-25$ years, their numbers are relatively high. The category refers to millennial generation consumers, who in research on consumer behaviour have been shown to have unique characteristics in their consumption patterns, so marketers also need to learn about these.

This study's limitations include the sample size and the suitability of the sample criteria, so that it is expected to give better results . Future research should focus on a more even distribution of demographic aspects in order to generalise the research results. The moderating effect of religiosity on the perceived Islamic value relationship on consumer satisfaction shows a significant result of $p=0.08$, which means that this value can be considered significant at the level of $p<0.1$. The model was validated by measurement of the perceived value of Muslim customers; other studies could attempt to validate this model with all customers.

Future research could also incorporate other dimensions and industries;for instance, the hospitality industry and perceived luxury value. Furthermore, as most studies examine perceived value by employing self-administered surveys, future research could employ experimental designs to observe how manipulation of the perceived value of services influences behaviour and loyalty. Additionally, with the prevalent influence of perceived value on consumer satisfaction, examining this influence on customer satisfaction with religiosity as a moderator could provide both theoretical and managerial contributions.

\section{REFERENCES}

Agarwala, R., Prashant, M., \& Ramendra, S. (2018). Religiosity and consumer behaviour: A summarizing review. Journal of Management, Spirituality $\mathcal{E}$ Religion, 16(1), 32-54.

Alam, S. S., Rohani, M., \& Badrul, H.K. (2011). Is religiosity an important determinant on Muslim consumer behaviour in Malaysia? Journal of Islamicic Marketing, 2(1), 83-96.

Atchison, J. (1990). Language and mind: Psycholinguistics. An Encyclopedia of Language, (10), 186-204.

Bosnjak, M., Carroll, A. B., Dong-Jin, L., Grace B. Y., \& M. Joseph, S. (2014). Selfexpressiveness in sport tourism: Determinants and consequences. Journal of Travel Research, 55(1), 125-134.

Cho, Y.J., Pei-W, F., \& Chi-Cheng, W. (2017). Popular research topics in marketing journals, 1995-2014. Journal of Interactive Marketing, 40(C), 52-72.

Chung, J., \& Gary, S. M. (2003) . Exploring social desirability bias. Journal of Business Ethics, 44(4), 291-302. 
Cooper, D.R., \& Schindler, P.S. (2014). Business research methods. (12th ed.). McGraw-Hill Irwin.

Dahl, A., \& Jimmy, P. (2015). A historical review and future research agenda for the field of consumer satisfaction, dissatisfaction, \& complaining behaviour. Journal of Consumer Satisfaction, Dissatisfaction \& Complaining Behaviour, 28.

Dubois, B., \& Laurent, G. (1994). Attitudes toward the concept of luxury: an exploratory analysis. Asia-Pacific Advances in Consumer Research, 1(2), 273-278.

Eid, Riyad. (2013). Integrating muslim customer perceived value, satisfaction, loyalty and retention in the tourism industry: An empirical study. International Journal of Tourism Research, 17(3), 249-260.

Eid, Riyad., Hatem, \& El-Gohary. (2015). The role of Islamicic religiosity on the relationship between perceived value and tourist satisfaction. Tourism Management, 46(C), 477-488.

El-Adly, M., \& Eid, R. (2017). Dimensions of the perceived value of malls: Muslim shoppers' perspective. International Journal of Retail $\mathcal{E}$ Distribution Management, 45(1), 40-56.

Gayatri, G., Chris, C., Gillian, S. M., \& Margee Hume. (2005). Understanding service quality from the Islamic customer perspective. ANZMAC 2005 Conference: Services Marketing.

Hair, J. F., Black, W. C., Babin, B. J., \& Anderson, R. E. (2014). 7th Multivariate data analysis. Essex: Pearson Education.

Hamzah, S. R., Turiman, S., Steven, E. K., Azimi, H., \& Ezhar, T. (2014). Youth hedonistic behaviour: Moderating role of peer attachment on the effect of religiosity and worldview. International Journal of Adolescence and Youth, 19(4), 419-433.

Havlena, W. J., \& Holbrook, M. B. (1986). The varieties of consumption experience: Comparing two typologies of emotion in consumer behaviour. Journal of Consumer Research, 13(3), 394-404.

Hirschman, E. C., \& Morris B. Holbrook. (1982). Hedonic consumption: Emerging concepts, methods and propositions. Journal of Marketing, 46(3), 92-101.

Homburg, C., Nicole, K., \& Wayne D. H. (2005). Do satisfied customers really pay more? A study of the relationship between customer satisfaction and willingness to Pay. Journal of Marketing, 69(2), 84-96.

Hui, T.K., David, W., \& Alvin, H. (2007). Tourists' satisfaction, recommendation and revisiting Singapore. Tourism Management, 28(4), 965-975.

Jin, N., Ben, Goh., Lyn, H., \& Jingxue, J. Y. (2015). Predictors and outcomes of perceived image of restaurant innovativeness in fine-dining restaurants. Journal of Hospitality Marketing \& Management, 24(5), 457-485.

Khalid, N. R., Che, A.C.W., Syed, S. A., \& Suraya, A.M. (2018). Cosmetic for modern consumer: The impact of self congruity on purchase intention. International Journal of Asian Social Science, 8(1), 34-41.

Kotler, P. \& Keller, K.L. (2016). Marketing management (15th ed). Upper Saddle River, New Jersey: Pearson Education, Inc.

Lee, S, \& Miyoung, J. (2014). Enhancing online brand experiences: An application of congruity theory. International Journal of Hospitality Management, 40(2014), 49-58. 
Ligas, M., \& Arjun, C. (2012). The moderating roles of shopper experience and store type on the relationship between perceived merchandise value and willingness to pay a higher price. Journal of Retailing and Consumer Services, 19(2), 249-258.

Lipka, M., \& Conrad, H. (2015). Why Muslims are the world's fastest-growing religious group. Pew Research Center.

Luo, X., \& Christian, H. (2007). Neglected outcomes of customer satisfaction. Journal of Marketing, 71(1), 133-149.

Maulan, S., Nor, A.U., \& Maisarah, A. (2016). Measuring halal brand association (HalBA) for Islamic banks. Journal of Islamicic Marketing, 7(3), 331-354.

Mokhlis, S. (2009). Relevancy and measurement of religiosity in consumer behaviour research. International Business Research, 2(3), 75-94.

Nwankwo, S., Nicolas, H., \& Meryem, K. (2014). Consumer value, motivation and purchase intention for luxury good. Journal of Retailing and Consumer Service, 21(5), 735-744.

Oliver, R. L. (1977). Effect of expectation and disconfirmation on postexposure product evaluations: An alternative interpretation. Journal of Applied Psychology, 62(4), 480-486.

Peng, N., Annie, C., \& Kuang-Peng, H. (2018). Examining consumers intentions to dine at luxury restaurants while traveling. International Journal of Hospitality Management, 71, 59-67.

Pham, H.S.T., \& Mohammad, F.A. (2017). Antecedents and consequences of online customer satisfaction: A holistic process perspective. Technological Forecasting $\mathcal{E}$ Social Change, 124(C), 332-342.

Razzaq, Z., Ali, R., Salman, Yousaf., \& Zhao, H. (2018). The Impact of utilitarian and hedonistic shopping values on sustainable fashion consumption: The moderating role of religiosity. Global Business Review, 19(5), 1-16.

Ryu, K., Heesup, H., \& Soocheong, J. (2010). Relationships among hedonic and utilitarian values, satisfaction and behavioural intentions in the fastcasual restaurant industry. International Journal of Contemporary Hospitality Management, 22(3), 416-432.

Sheth, J. N., Bruce, I.N., \& Barbara, L.G. (1991). Why we buy what we buy: A theory of consumption values. Journal of Business Research, 22(1), 59-170.

Siala, H. (2013). Religious influences on consumers' high-involvement purchasing decisions. Journal of Services Marketing, 27(7), 579-589.

Sirgy, M. J. (1985). Using self-congruity and ideal congruity to predict purchase motivation. Journal of Business Research, 13(3), 195-206.

Sirgy, M. J., Dong-Jin. L., Grace., B.Y., Eda, G.A., John, T., \& Ahmet, E. (2016). Self expressiveness in Shopping. Journal of Retailing and Consumer Services, 30, 292-299.

Smith J. B., \& Mark, C. (2007). Customer value creation: A practical framework. Journal of Marketing Theory and Practice, 15(1), 7-23.

Taylor, V.A., Diane, H., \& Gaëlle, M.U. (2017). Millennial consumer responses to Christian religious symbols in advertising: A replication study. Journal of Empirical Generalisations in Marketing Science, 17(1), 1-18.

Thomson, R. (2017). Outpacing the mainstream. State of The Global Islamicic Economy Report 2017/2018. 
Yang, W., Mattila, A. S. (2016). Why do we buy luxury experiences?: Measuring value perceptions of luxury hospitality services. International Journal of Contemporary Hospitality Management, 28(9), 1848-1867.

Yoo, J., \& Park, M. (2016). The effects of e-mass customization on consumer perceived value, satisfaction, and loyalty toward luxury brands. Journal of Business Research, 69(12), 5775-5784.

\section{APPENDIX}

\begin{tabular}{|c|c|c|}
\hline & Item & Reference model \\
\hline & Functional Value & $\begin{array}{c}\text { Adopted from: } \\
\text { Peng and Cheng (2018). }\end{array}$ \\
\hline 1 & The fine dining restaurant has an aesthetic (enjoyable) atmosphere. & \\
\hline 2 & The fine dining restaurant's dishes are fantastic. & \\
\hline \multirow[t]{2}{*}{3} & The fine dining restaurant provided friendly service. & \\
\hline & Symbolic value & $\begin{array}{c}\text { Adopted from: } \\
\text { Yoo and Park (2016), Chen and Peng } \\
\text { (2018). }\end{array}$ \\
\hline 4 & \multicolumn{2}{|c|}{ People argue that dining at a fine dining restaurant is considered to be a symbol of social status. } \\
\hline 5 & \multicolumn{2}{|c|}{ People argue that dining at a fine dining restaurant can help express their self-image. } \\
\hline 6 & \multicolumn{2}{|c|}{ People argue that dining at fine dining restaurants can be used to communicate their identity. } \\
\hline & Hedonic value & Yang and Mattila (2016) \\
\hline 7 & I visited a fine dining restaurant to experience the pleasure. & \\
\hline 8 & Dining at fine dining restaurants can give me joy. & \\
\hline 9 & Dining at fine dining restaurants can let me indulge myself. & \\
\hline
\end{tabular}

Islamic Value Eid (2013), Adly and Eid (2017), Ahmad

\footnotetext{
10 I feel calm when I can pray on time because of the availability of prayer rooms at fine dining restaurants.

11 I feel calm because I can enjoy halal food at fine dining restaurants.

12 I feel calm because there are no advertisements (images) that contain elements of sensuality in fine dining restaurants.

13 The fine dining restaurants I have been to provide fair service to all customers.

14 The fine dining restaurants I have been to had waiters with a humble attitude when serving customers. Adopted from:

Customer Satisfaction

Eid and Gohary (2015), Yoo and Park
} (2016).

\begin{aligned} & \hline $\mathbf{1 5}$ I am happy with my decision to dine at the fine dining restaurant. \\ & \hline $\mathbf{1 6}$ Dining at this restaurant was a wise choice. \\ & \hline $\mathbf{1 7} \begin{array}{l}\text { Eating at the fine dining restaurant was the right choice because the restaurant I went to gave me the experience } \\ \text { I expected. }\end{array} \\ &$\hline\end{aligned}

Willingness to Pay More

Ligas and Chauduri (2012), Pham and

Ahammad (2017)

\begin{tabular}{|c|c|}
\hline 18 & I will go to this restaurant again in the future, even though the price is a bit high. \\
\hline 19 & I am willing to pay a little more at this restaurant than at any other restaurant that offers the same benefits. \\
\hline 20 & I will switch to another restaurant at a lower price. \\
\hline & $\begin{array}{l}\text { Adopted from: } \\
\text { Worthingthon (2003) }\end{array}$ \\
\hline 21 & People argue that religion is the basis for all life goals. \\
\hline 22 & People argue that it is essential to take time to understand religious beliefs. \\
\hline 23 & People argue that it is essential to take time for self-reflection. \\
\hline 24 & People argue that religion gives meaning to life. \\
\hline 25 & People argue that belief in religion affects all decisions in life. \\
\hline
\end{tabular}


This page is intentionally left blank 